Vol. 12, No. 2, Juli 2021

\title{
TINJAUAN HUKUM ISLAM TERHADAP MEKANISME AGEN BRILINK PADA PT. BANK RAKYAT INDONESIA TBK. UNIT SUKAMULIA, AGEN ULONG KHASBI PRATAMA DI DESA GAPUK KECAMATAN. SURALAGA
}

\author{
Ratnawati \\ IAI Hamzanwadi Lombok Timur \\ Email: watiratna971@yahoo.com
}

\begin{abstract}
Abstrak
Penelitian ini bertujuan untuk mengetahui Tinjauan Hukum Islam Terhadap Mekanisme Agen Brilink Pada Pt. Bank Rakyat Indonesia Tbk. Unit Sukamulia, Agen Ulong Khasbi Pratama Di Desa Gapuk Kecamatan. Suralaga. Jenis penelitian ini menggunakan Metodologi penelitian kualitatif yang bersifat senomenologis yaitu berusaha memahami arti peristiwa yang terjadi di lapangan dan situasi tertentu untuk mendapatkan data yang kongkrit maka peneliti perlu mengadakan pendekatan peneliti, kehadiran peneliti, sumber data, metode pengumpulan data,metode analisa data, dan keasahan data. Hasil penelitian dan pembahasan menunjukan bahwa syarat perjanjian keagenan terdiri dari agen perorangan, memiliki sumber penghasilan kegiatan usaha tetap, dan memiliki surat legalitas usaha. Tahap perusedur dan pengisian formulir, peyerahan dokumen, pemeriksaan dokumen, putusan persetujuan kerjasama dan peyerahan sartifikat agen. POJK dan Bank BRI tidak memasukan syarat kecakapan untuk calon agen BRILink.
\end{abstract}

Kata kunci : Tinjauan hukum islam, mekanisme, Agen BRILink

\begin{abstract}
This study aims to determine the Islamic Law Review Against the Brilink Agent Mechanism at Pt. Bank Rakyat Indonesia Tbk. Sukamulia Unit, Ulong Khasbi Pratama agent in Gapuk Village, District. Suralaga. This type of research uses a qualitative research methodology that is senomenological in nature, namely trying to understand the meaning of events that occur in the field and certain situations to obtain concrete data. data. The results of the research and discussion show that the terms of the agency agreement consist of individual agents, have a permanent source of income for business activities, and have a business legality letter. The procedure stage and filling out forms, submitting documents, examining documents, deciding on cooperation agreements and submitting agent certificates. POJK and Bank BRI do not include the qualification requirements for prospective BRILink agents.
\end{abstract}

Keywords: Islamic law review, mechanism, BRILink agent 


\section{Vol. 12, No. 2, Juli 2021}

\section{PENDAHULUAN}

Namun di era globalisasi membuat dunia menjadi begitu terbuka, termasuk dalam dunia bisnis dan perbankan. Masyarakat sangat membutuhkan kehadiran Bank sebagai saran penyimpanan maupun membentuk dalam usaha masyarakat baik usaha kecil maupun menengah ke atas. Maraknya Bank-Bank yang hadir di Indonesia dengan berbagai layanan dan produk-produk andalan untuk menarik perhatian khalayak merupakan hal yang cukup variatif dalam dunia perbangkan.

Berbagai cara untuk menarik nasabah yang baru supaya menjadi nasabah tetap maupun mempertahankan setiap nasabah menjadi tantangan khusus bagi setiap Bank. Nasabah merupakan nafas kehidupan setiap Bank untuk maju dan tetap menggunakan jasa dan layanan produknya.

Oleh karena itu, maka hal yang penting sebagai karyawan yang baik adalah bagaimna mengerti keinginan pelanggan (nasabah) dan senantiasa memberikan nilai tambah di mata konsumen. Nilai tambah itu antara lain, memberikan informasi yang jelas dan lengkap kepada konsumen, pelayana yang cepat, tepat dan kenyamanan pelayanan.

Kesuksesan pemasaran Bank dapat dicapai melalui fokus pada kualitas pelayanan untuk memuaskan pelanggan.

Dalam menuntut tingkat kepuasan, seseorng pelanggan sering kali melihat Dari nilai suatu kinerja pelayanan yang diterima dari suatu proses pembelian produk jasa. Untuk menghindari supaya tidak terjadi perbedaan persepsi tentang apa yang diberikan oleh perusahaan dengan apa yang dibutuhkan oleh konsumen itu sendiri, maka manajemen perusahaan perlu untuk mengidentifikasi apa yang dibutuhkan oleh nasabah secara tepat.

PT Bank Rakyat Indonesia Tbk, didirikan sejak tahun 1895 di dasarkan pada masyarakat kecil sampai sekarang ini tetap konsisten pada komitmennya untuk senantiasa membantu usaha kecil yang kini lebih populer di sebut micro banking, hal ini antara lain terceremin pada perkembanan melalui penyaluran kerja sama dengan nasabah BRI yang di sebut dengan BRILink yang mna BRILink merupakan perluasan layanan BRI dimana BRI menjalani kerja sama dengan nasabah BRI sebagai Agen yang dapat melayani kerjasama dengan nasabah BRI sebagai Agen yang dapat melayani transaksi perbankan bagi masyarakat secara real time onlin menggunakan fitur EDC mini ATM BRI dengan konsep sharing fee yang diberikan konpetatif.

Rakyat Indonesia BK menerapkan 


\section{Vol. 12, No. 2, Juli 2021}

pekerjaan kepada pekerja khususnya pada jajaran front liners agen senantiasa memberikan pelayanan yang terbaik melalui penawaran prodok sesuai kebutuhan nasabah, berepati kepada nasabah pada saat memberikan pelayanan, senantiasa menyambut nasabah dengan greting $3 \mathrm{~S}$ seyum, sapah dan salam, dan tidak lupa selalu menyebutkan nama nasabah pada saat mengakhiri pelayanan. Sehingga kualitas pelayanan yang di berikan oleh pekerja dapat memuaskan nasabah secara keseluruhan.

Salah satu sarana pelayanan yang memudahkan nasabah dalam kegiatan transaksi perbankan adalah vasilitas mesin edesi eliktronik data komputer (seiring dengan persaingan yang semakin ketat antar bank yang satu dengan yang lain, kualitas pelayanan yang tinggi termasuk di dalamnya layanan kemudahan pembayaran, merupakan sebuah tuntutan. (Bank Unit Sukamulia. 2019 ).

\section{METODE PENELITIAN}

Menurut sumber data atau informasi yang diperoleh dalam kegiatan penelitian, maka jenis penelitian yang peneliti gunakan adalah penelitian lapangan (field research).

Tujuan penelitian studi kasus atau lapangan adalah mempelajari secara intensif latar belakang, status terakhir dan interaksi lingkungan yang terjadi pada suatu satuan sosial seperti individu, kelompok, dan lembaga.

Berkaitan dengan jenis penelitian ini, maka data yang digunakan adalah data sekunder, wawancara dibuat untuk melengkapi data sekunder. Menurut Zuldafrial data sekunder adalah data yang diperoleh atau dikumpulkan oleh orang yang melakukan penelitian dari sumber-sumber yang telah ada.

Teknik pengumpulan data yang dilakukan peneliti dalam penelitian ini adalah questionnaire yaitu daftar pertanyaan yang mencakup semua pernyataan dan pertanyaan yang akan digunakan untuk mendapatkan data, baik yang dilakukan melalui telepon, surat atau bertatap muka. Penyebaran angket diberikan kepada masyarakat yang bertransaksi di agen BRILink Ulong Khasbi Pratama Cabang Gapuk Kec.Suralaga Lombok Timur.

Analisis data dilakukan secara deskriptif kualitatif, analisis kualitatif menurut Abdulkadir Muhammad adalah menguraikan data secara bermutu dalam bentuk kalimat yang teratur, runtun, logis, tidak tumpang tindih dan efektif, sehingga memudahkan interpretasi data dan pemahaman hasil analisis. 


\section{Vol. 12, No. 2, Juli 2021}

\section{HASIL PENELITIAN}

Agen BRILink merupakan salah satu perantara yang telah di pilih oleh BRI guna memberikan kemudian bagi masyarakat pelosok untuk bisa menggunakan layanan perbankan.

Kehadiran Agen BRILink di sumber positif, pasalnya seseorang tidak perlu lagi datang ke kantor BRI ngantri hanya untuk bayar tagihan atau untuk melakukan transfer. Bukan itu saja, seseorang bisa beli pulsa listrik, pulsa hp, dan semua layanan PPOB telah terintegrasi pada Agen BRILink.

Bisnis online usaha rumahan tidak ingin memaparkan cara jadi Agen BRILink. Namun ingin mengeluaskan hukum Agen BRILink dalam pandangan Islam. Pasalnya saat ini, gemuruh berkerja atau menjadi nasabah pinjaman Bank itu di kategorikan riba.

Dalam kegiatannya melakukan transasksi perbankan yang diselenggarakan melalui agen BRILink, nasabah juga mendapatkan perlindungan atas haknya untuk mendapatkan ganti rugi atas kerugian yang dideritanya. Hal tersebut sesuai dengan Pasal 22 huruf f POJK No. 19/POJK.03/2014 yang menegaskan bahwa, "Bank penyelenggara wajib bertanggungjawab atas kerugian nasabah yang timbul karena perbuatan dan tindakan agen yang termasuk dalam cakupan layanan agen sesuai dengan yang dicantumkan dalam perjanjian kerjasama". Namun apabila kerugian disebabkan karena kesalahan atau kelalaian agen maka agenlah yang harus bertanggungjawab sepenuhnya atas kerugian yang diderita oleh nasabah. Tanggung jawab dalam hubungan keagenan tersebut juga tertuang dalam perjanjian kerjasama antara BRI dan agen BRILink.

Bukan hanya perjanjian agen BRILink yang mengatur secara jelas pihak yang bertanggungjawab atas kerugian nasabah, namun BRI juga memberikan ruang kepada nasabah untuk dapat menyampaikan keluhan- keluhannya langsung kepada agen BRILink. Apabila, agen tidak dapat menangani keluhan nasabah atau nasabah kurang puas atas tanggapan yang diberikan oleh agen BRILink maka keluhan nasabah akan diteruskan oleh agen BRILink atau nasabah langsung kepada BRI untuk mendapatkan tanggapan secara langsung.

Menjaga kepercayaan nasabah dalam penyelenggaraan Laku Pandai merupakan hal yang penting untuk memenuhi hak nasabah atas keamanan kerahasiaan data nasabah beserta simpanannya, mengingat agen Laku Pandai yang memberikan pelayanan jasa keuangan kepada nasabah dan secara langsung akan mengetahui data nasabah beserta simpanannya. 


\section{Vol. 12, No. 2, Juli 2021}

Oleh karena itu kewajiban menjaga rahasia data nasabah bukan hanya dibebankan kepada bank penyelenggara saja namun juga kepada agen Laku Pandai.

Hal tersebut jelas diatur dalam POJK No. 19/POJK.03/2014 dan SEOJK No.6/SEOJK.03/2015 yang menyatakan bahwa rahasia bank di dalam pelaksanaan penyelenggaraan Laku Pandai merupakan tanggung jawab pihak bank dan agen. Adapun hak dan kewajiban agen dan nasabah serta pelinudungan nasabah tertuang dalam pasal 34 bank penyelenggara wajib menerapkan perlindungan konsumen.

Mengingat data dan simpanan nasabah merupakan rahasia bank maka BRI dan agen BRILink sepakat untuk melindungi data nasabah beserta simpanannya dengan tidak memberikannya kepada pihak lain selain BRI dengan tujuan apapun, termasuk untuk tujuan promosi atau komersial lainnya tanpa persetujuan nasabah. Hal tersebut dengan tegas diatur dalam perjanjian kerjasama antara BRI dan agen BRILink.

HUKUM ISLAM BERTERANSAKSI DI AGEN BRILINK KEC.SURALAGA

$$
\text { Yang menjadikan orang }
$$

mempertanyakan atau meragukan status hukum dari agen BRILink adalah jangan sampai aktivitas dari BRILink tersebut tergolong atau termasuk dengan riba.

Batasan riba seperti yang diutarakan oleh sahabat Fudholah Bin dalam hadits riwayat By Haqy mengatakan bahwa "semua hutang yang memberikan manfaat kembali kepada pemberi hutang. Tambahan atau manfaat ini statusnya sebagai riba". Oleh sebab itu, tidak semua kelebihan dapat di sebut sebagai riba. Tambahan atau fee yang di dapatkan dari transaksi jual beli bukan dalam setatus hutang itu sifatnya sebagai ujroh, dan itu boleh saja dan halal.

\section{KESIMPULAN}

BRILink dalam pandangan Islam. Pasalnya saat ini, gemuruh berkerja atau menjadi nasabah pinjaman Bank itu di kategorikan riba. Walaupun pendapat mengenai riba ini sudah berlangsung cukup lama. pandangan Prof. Quraish shihab mengenai riba dalam Islam.

Adapun dampak dari Bank Tunggal rakyat terhadap perekonomian msyarakat di kec.Suralaga kab. Lombok timur nusa tenggara barat yakni mengakibatkan berbagai rencana terhadap segenap lapisan masyarakat hal ini dari sisi ekonomi Bank tunggal karya yang memperaktik riba telah membagi manusia menjadi dua kelompok yaitu: a) Kelompok yang hidup dalam kemewahan,bersenang-senang dengan 
keringat dan jeri payah orang lain. b). Kelompok yang terjerumus dalam kekafiran ,kelompok ini adalah orang- orang yang membanting tulang bekerja sedangkan hasil daripada usahanya dinikmati oleh pemilik harta yang menumpuk kekayaan tanpa untung/rugi. c). Dampak positifnya meskipun banyak terjadi pertanyaan dikalangan msyarakat dalam status hukum dalam aktivitas dan transaksi yang terjadi di BRILink dalam tinjauan hukum islam, minat masyarakat dalam bertransaksi begitu juga dalam dunia bisnis dan perbangkan, masyarakat sangat membutuhkan kehadiran Bank sebagai saran peyimpanan maupun membentuk dalam usaha masyarakat baik usaha kecil atau menengah ke atas.

Mengenai hukum BRILink. Dapat di tarik kesimpulan bahwa kegiatan BRILink seperti trasfer, beli pulsa, biaya listrik itu sifatnya ujroh/ upah, bukan termasuk riba.

\section{DAFTAR PUSTAKA}

Armstrong, Michael and Baron, A. 1998. Performance Management: The New Realities. New York: Institute of personnel and Develoment.

Bernardin, H. John and Ressel, Joice E. A. 2003. Human Resources Management. New York: Mc Graw-Hill.

Bodroastuti, Pratiwi Indarjanti Tri, 2009. Pengaruh kemampuan, upayaindividual
Dan dukungan Organisasi Terhadap Kinerja. Jurnal sekolah tinggi ilmu Ekonomi Widya Manggala Semarang.

Dessler, Gary. 2003. Human Resoure Management Tenth Edition. New Jersey Prentice Hall.

Djarwantops dan pangestu, subagyo. 1996. Statikti Induktif Edisi Empat.Yoqyakarta: Badan percetakan Fakultas Ekonomi Universitas Gaja Mada.

Ghozali, Imam. 2005. Aplikasi Analisis Multivariate. Dengan program SPSS Badan penerbit Universitas Diponegoro, semarang.

H. B. Sutopo, 2006. Penelitian Kualitatif: Dasar Teori dan Terapannya Dalam penelitian. Surakarta: Universitas sebelas maret.

Hasibuang, melayu SP. 2005. Manajemen sumberdaya Daya manusia, edisi revisi.Jakarta: Bumi Aksara.

Ghozali, Imam. 2005. Aplikasi Analisis Multivariate. Dengan program SPSS Badan penerbit Universitas Diponegoro, semarang.

Indriantoro, Malayu SP. 2002. Metodelogi penelitian untuk Akuntansi dan manajemen. Cetakan 2. Yogyakarta: BPEE.

Irwan, prasetya. 1999. Logika Dan prosedur penelitian. Jakarta: SETIA-LAN press

Ivannacevich, konopaske, matteson, 2006. Perilaku dan manajemen Organisasi, Jakarta: Erlangga.

Kartono,kartini. 2001. Pemimpin dan kepemimpinan. Jakart: Rajawali press. 
Kartono,kartini. 2001. Pemimpin dan kepemimpinan. Jakart: Rajawali press.

Mahmudi. 2007. Manajemen kinerja sector publik. Yoqyakarta: UPP sekolah Tinggi Ilmu manajemen YKPN. 